\title{
Legisladores, captadores e assistencialistas: a representação política no nível local
}

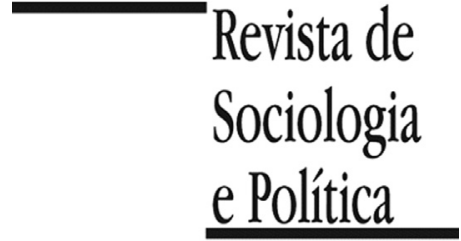

DOI 10.1590/1678-987317256207

\author{
Felix Lopez e Acir Almeida
}

\begin{abstract}
Resumo
O artigo analisa a representação política local, focando as percepções e práticas cotidianas dos vereadores. Em particular, analisam-se suas escolhas entre estratégias de representação clientelistas e universalistas. Utilizam-se dados originais de entrevistas abertas semiestruturadas com amostra não representativa de 112 vereadores de 12 municípios de Minas Gerais. Por meio de análise qualitativa, classificam-se os vereadores em três tipos, de acordo com sua principal estratégia de representação, a saber: "legislador", que se dedica mais às funções formais da vereança; "captador", que prioriza o atendimento de pedidos coletivos dos eleitores; "assistencialista", que prioriza o atendimento de pedidos particulares. Com base na literatura teórica sobre clientelismo, oferecem-se hipóteses explicativas das estratégias de representação dos vereadores, que são testadas estatisticamente utilizando-se um modelo probit multinomial. Os resultados sugerem que essas estratégias são qualitativamente distintas e que a probabilidade de ocorrência do tipo assistencialista é maior em municípios pequenos, crescente no acirramento da competição política e decrescente na volatilidade eleitoral. Também há evidência fraca de que essa probabilidade é decrescente na escolaridade do vereador e crescente no seu tempo de vereança.
\end{abstract}

Palavras-chave: representação política; clientelismo; assistencialismo; vereador; política local.

Recebido em 10 de Março de 2016. Aceito em 24 de Junho de 2016.

\section{Introduçãa ${ }^{1}$}

\footnotetext{
1 Versões preliminares deste artigo foram discutidas nos seguintes fóruns: $34^{\circ}$ Encontro Anual da Anpocs (ST23, Partidos e Sistemas Partidários); Interlegis/Senado Federal; Diretoria de Estado, Instituições e Democracia, do Instituto de Pesquisa Econômica Aplicada (DIEST/IPEA); Laboratório de Pesquisa em Comportamento Político, Instituições e Políticas Públicas, da Universidade de Brasília (LAPCIPP/UnB); e Programa de Pós-Graduação em Ciências Sociais, da Universidade Federal de Juiz de Fora (PPGCSO/UFJF). Os autores agradecem todas as críticas e sugestões recebidas, inclusive as de um parecerista anônimo da Revista de Sociologia e Política. Agradecem também a presteza e a gentileza dos vereadores e funcionários das câmaras
}

$\mathrm{E}$ xiste aparente consenso quanto à caracterização de que, no Brasil, a política local é predominantemente clientelista (Kerbauy 2005, p.350). Não obstante a literatura colecionar excelentes ensaios e análises sobre a ocorrência sistêmica do clientelismo, incluindo interpretações sobre sua gênese e dinâmica ao longo da nossa história (Queiroz 1976; Vianna 1987; Graham 1997; Leal 1997; Nunes 1997), tais estudos pouco ajudam na elucidação dos microfundamentos do fenômeno, particularmente na identificação das razões pelas quais políticos adotam práticas de representação clientelistas em vez de outras, mais universalistas. Investigações recentes sobre o clientelismo no nível local, por sua vez, abordam o cotidiano da representação por meio ou de perspectivas hermenêuticas - avaliando, em particular, as motivações subjetivas dos atores (Palmeira \& Goldman 1996; Kushnir 2000) - ou da descrição de como a representação é exercida em uma ou poucas localidades (Joffre Neto 2003; Lopez 2004). Não está entre os objetivos desses estudos, entretanto, a explicação sistemática do fenômeno².

Este artigo tem dois objetivos. Em primeiro lugar, identificar e compreender como a representação política é exercida no nível local, no Brasil, atentando especialmente para práticas clientelistas. Em segundo, testar algumas explicações da ocorrência desse padrão de representação. Para tanto, focamos a análise nos vereadores, como eles percebem e exercem a representação.

O foco na política local e, mais especificamente, nos vereadores, justifica-se pelas seguintes razões. Desde a promulgação da Constituição de 1988, os 
legislativas que participaram da pesquisa.

${ }^{2}$ Uma exceção é Castro,

Anastasia e Nunes (2009), que

avaliam empiricamente

potenciais condicionantes do

particularismo político entre

deputados estaduais, porém

sem chegar a um resultado

conclusivo.

${ }^{3}$ De acordo com Afonso (2010), ela passou de $8,5 \%$ para $18,5 \%$ no período.

${ }^{4}$ Calculado pelos autores com base em dados de STN (s.d.).

Para análise mais detalhada do crescimento das transferências da União, ver IPEA (2010, cap.3). municípios brasileiros têm adquirido importância crescente na execução de políticas públicas, inclusive na gestão de recursos financeiros. A título de ilustração, a fatia de recursos destinados aos municípios na receita disponível global mais que duplicou entre 1988 e $2009^{3}$, e o valor real das transferências de recursos da União para os municípios, para a execução de programas federais, aumentou em $66 \%$ entre 2001 e $2011^{4}$. Se a política local é de fato predominantemente clientelista, então existe risco considerável de a ampliação do papel dos municípios reduzir, em vez de aumentar, a eficiência e a eficácia na execução das políticas públicas (García-Guadilla \& Pérez 2002). Os vereadores, por sua vez, são atores cruciais na política municipal, por ao menos duas razões. Primeiro, porque cabe a eles fiscalizar a execução das políticas públicas pelo Executivo local. Segundo, porque eles são os representantes que mantêm vínculos mais próximos e frequentes com os cidadãos, constituindo-se talvez no principal canal de mediação dos últimos nas esferas política e administrativa, em diferentes níveis de governo.

A título de antecipação dos resultados, entrevistas em profundidade com 112 vereadores de 12 municípios mineiros revelaram a existência de três tipos de representante, cada qual classificado como "legislador", "captador" ou "assistencialista". O primeiro notabiliza-se por sua dedicação a ao menos uma das funções formais da vereança, que são legislar e fiscalizar o Executivo. Os outros dois tipos se dedicam mais a atividades extralegislativas, de atendimento a pedidos de eleitores. A natureza do pedido que priorizam, se predominantemente particular ou coletivo, é o que os distingue. O captador dedica-se mais ao atendimento de pedidos coletivos, geralmente voltados para ações de infraestrutura no município. Para realizar essa atividade, o vereador precisa atuar na captação de recursos públicos, no Executivo municipal ou em outras esferas de governo. $\mathrm{O}$ assistencialista, por fim, dedica seu tempo e esforço principalmente ao atendimento de pedidos particulares, ou seja, que beneficiam apenas um eleitor e sua família. Conceitualmente, o assistencialista pratica uma forma de particularismo político, que entendemos ser de natureza clientelista. Ele se contrapõe ao legislador, cujas atividades são, a princípio, universalistas. Menos clara, no entanto, é a classificação conceitual do captador. Nossos achados empíricos sugerem que esse tipo segue lógica distinta da que rege aquela contraposição.

Apoiados na literatura que investiga os condicionantes do clientelismo, testamos algumas hipóteses explicativas da probabilidade de um vereador adotar esse padrão de representação. Os condicionantes incluem fatores demográficos, socioeconômicos, políticos e, em alguma medida, culturais. Os resultados de análises de regressão permitem concluir com razoável confiança que a probabilidade de um vereador ser do tipo assistencialista é maior em municípios pequenos, crescente no acirramento da competição política e decrescente na volatilidade eleitoral. Também se encontra evidência fraca de que essa probabilidade é decrescente na escolaridade do vereador e crescente no seu tempo de vereança.

O restante deste artigo está organizado da seguinte forma. Na próxima seção, revisamos a literatura sobre clientelismo, particularismo e representação política, identificando os fatores que potencialmente condicionam a incidência do primeiro. Em seguida, na terceira seção, apresentamos o desenho da pesquisa, particularmente a estratégia de seleção e os procedimentos de coleta dos dados. Na quarta, realizamos uma análise descritiva sobre como os vereadores percebem e exercem a representação. Com base nos resultados dessa análise, identificamos os três tipos de vereadores mencionados anteriormente (legislador, captador e assistencialista). Na quinta seção, utilizamos análise de regressão para testar potenciais correlatos desses tipos, apontados pela literatura. Por 
último, resumimos os principais achados e tecemos algumas considerações finais.

\section{Clientelismo, particularismo e representação política}

\footnotetext{
5 O conceito de responsividade refere-se tanto à capacidade de resposta do sistema político às demandas dos cidadãos quanto à consistência entre as políticas produzidas e aquelas demandas, sendo a responsividade maior quando as respostas são mais rápidas e mais consistentes.

${ }^{6}$ Responsabilização refere-se às condições existentes para que os cidadãos tanto identifiquem os responsáveis pelas políticas produzidas quanto os recompensem (ou punam) em função dessas políticas, sendo a responsabilização maior quando tais condições são mais favoráveis.

7 A literatura sobre clientelismo apresenta grande diversidade teórica e conceitual, circunscrevendo um espectro que vai da Economia à Antropologia Política. Neste artigo, deixamos de lado esse importante debate e adotamos o conceito mais usado por cientistas políticos. Para discussões mais amplas, ver Hicken (2011) e Hilgers (2011).
}

O modelo de representação política tido como o mais apropriado para promover responsividade ${ }^{5}$ e responsabilização ${ }^{6}$ tem a seguinte forma estilizada: (1) partidos políticos competem pelo voto com base em programas de governo distintos e que refletem suas percepções sobre os interesses dos eleitores; (2) os eleitores identificam os programas dos partidos e votam naqueles cujas políticas públicas são as mais próximas das suas preferências ideais; e (3) uma vez no governo, o partido vencedor executa seu programa. Esse processo se repete regularmente, em eleições livres e competitivas. Nesse modelo, a relação de representação tem bases programáticas e as políticas públicas implementadas são universalistas (Kitschelt \& Wilkinson 2007).

Além desse modelo, de natureza programático-universalista, a literatura identifica outros: o corporativista, o pluralista e o clientelista (Piattoni 2001, pp.200-206). Nosso interesse é o modelo clientelista, que, no Brasil, e especialmente no nível local, tem história longa e persistente, embora marcada por altos e baixos (Carvalho 1997). O clientelismo é uma forma de particularismo político, isto é, de distribuição de recursos públicos a grupos específicos, com repartição dos custos correspondentes por toda a população. Seu traço distintivo é o fato de o representante condicionar a entrega do benefício ao voto do eleitor, e vice-versa ${ }^{7}$.

De forma estilizada, o modelo de representação clientelista democrática ${ }^{8}$ pode ser descrito como segue: (1) partidos (ou candidatos) competem pelo voto com base na sua capacidade e credibilidade de entregar bens e serviços diretamente aos eleitores; (2) os eleitores votam com base nas suas avaliações acerca daquela capacidade e credibilidade; e (3) uma vez no governo, o partido (ou candidato) vencedor usa recursos públicos para entregar os bens e serviços prometidos, de forma seletiva, privilegiando os eleitores que o apoiaram. Também nesse caso o processo se repete regularmente, em eleições livres e competitivas. Em razão da natureza seletiva e condicional das suas políticas públicas, o modelo clientelista tende a apresentar baixa responsividade, sendo, por isto, objeto de severas críticas normativas. Ele também é criticado em razão tanto dos seus resultados ineficientes na provisão de bens e serviços públicos quanto da sua lógica excludente, que reduzem a adesão dos cidadãos ao regime democrático.

\section{II.1. Microfundamentos do clientelismo}

\footnotetext{
${ }^{8}$ A expressão "democrática" faz-se necessária para deixar fora do escopo da discussão o clientelismo em sociedades autoritárias ou tradicionais, onde a assimetria de poder entre representante $\mathrm{e}$ representado tende a ser maior. Em contextos democráticos, a liberdade de escolha do eleitor torna essa relação mais equilibrada.
}

O clientelismo é uma relação de troca e, por isso, ele é mais bem definido e analisado no nível das interações entre indivíduos em vez de no nível organizacional ou no sistêmico (Hilgers 2011). Em face disso, dois desafios teóricos se impõem. O primeiro é identificar os mecanismos que tornam a troca clientelista sustentável. Que garantias o representante tem de que o eleitor honrará a promessa de votar nele após receber o benefício? Por outro lado, que garantias o eleitor tem de que, após dar o seu voto a um candidato, este irá entregar o benefício prometido, uma vez eleito? Em outras palavras, como cada parte da relação pode se comprometer de forma crível a cumprir sua promessa? Outro desafio teórico é identificar as condições que favorecem a incidência e a intensidade da relação clientelista.

Vejamos, primeiro, o problema do comprometimento. A troca clientelista não ser simultânea e o voto ser secreto tornam a relação um jogo não cooperativo. Os atores veem-se diante de um dilema dos prisioneiros: não obstante a 
${ }^{9}$ Para uma discussão mais geral dos correlatos do clientelismo, inclusive entre países, ver Kitschelt (2000). troca ser mutuamente benéfica, a ausência de mecanismo crível de comprometimento faz com que a estratégia dominante para ambos os atores seja não cooperar, isto é, renegar sua promessa. Como, então, a relação clientelista se sustenta? A resposta a esta pergunta varia de acordo com a abordagem analítica. Na perspectiva da Antropologia Política, ela se sustenta, em grande medida, sobre normas de reciprocidade e compromissos morais de lealdade que, por sua vez, são fundados em laços pessoais, criados pela interação direta e frequente entre eleitor e representante. As sanções sociais que acompanham a violação daquelas normas seriam suficientes para garantir que ambas as partes cumprissem o acordo. Nessa abordagem, o clientelismo refletiria, por assim dizer, mais que uma troca, uma forma de sociabilidade (Davis 1977, cap.4; Weingrod 1977; Briquet 1998; NUAP 1998; Bailey 2001, cap.8; Palmeira \& Heredia 2010).

Na perspectiva da ciência política e, mais especificamente, do modelo do ator racional, a ocorrência periódica de eleições competitivas seria suficiente para tornar a relação clientelista autossustentável (Stokes 2005). A perspectiva de que a relação é contínua permite aos atores adotarem estratégias de punição no caso de a outra parte não cooperar. A perspectiva de punição em eleições subsequentes funciona como mecanismo crível de comprometimento: cada ator cumpre a sua promessa para evitar a punição da outra parte e, assim, garantir o fluxo de benefícios da relação clientelista. É verdade que o fato de o voto ser secreto inviabiliza o perfeito monitoramento da cooperação do eleitor. No entanto, isso não é suficiente para inviabilizar o equilíbrio do jogo, pois ao representante basta saber como grupos suficientemente pequenos de eleitores votaram (por exemplo, de uma zona ou seção eleitoral), de forma que aquele possa induzir nos últimos a crença de que a probabilidade de entrega do benefício está positivamente associada à contrapartida do voto (Medina \& Stokes 2007, p.75).

Se a troca clientelista é comportamento de equilíbrio, quais fatores condicionam a sua ocorrência e intensidade? Para os propósitos desta pesquisa, interessa-nos identificar apenas os fatores de potencial relevância para o clientelismo entre os municípios e vereadores brasileiros ${ }^{9}$. O primeiro, reconhecido de forma praticamente unânime pela literatura, é o nível de desenvolvimento econômico ou, mais especificamente, a extensão da pobreza (Hicken 2011, p.299). As necessidades decorrentes da pobreza são mais urgentes e, assim, fazem com que o indivíduo demande com maior intensidade benefícios que são materiais, diretos e imediatos. Em democracias competitivas, onde os candidatos são maximizadores da probabilidade de serem eleitos, aquela demanda não apenas é respondida como, sempre que possível, o provedor da política procura condicionar o benefício ao voto, pois isso maximiza seu retorno eleitoral. Assim, a resposta dos candidatos à demanda dos eleitores por benefícios materiais diretos tende a ser a oferta de políticas particularistas segundo lógica clientelista.

Outro fator potencialmente relevante para a incidência do clientelismo em uma unidade política é o tamanho da sua população. De acordo com as abordagens antropológicas e sociológicas, as pequenas cidades, em razão do maior contato direto entre os seus habitantes, são mais favoráveis à formação do padrão comunitário de sociabilidade vis-à-vis o societário (Tönnies 1947; Brancaleone 2008), o que influi diretamente no papel que a confiança interpessoal desempenha para ativar e sustentar relações de tipo clientelista. O tamanho da população também influencia os valores da sociedade, no sentido de que moradores de pequenas cidades são menos propensos a considerar a relação clientelista em termos puramente instrumentais (Schmidt et al. 1977, para inúmeros exemplos), tornando-a normativamente mais enraizada. Por essas razões, espera-se que municípios pequenos tenham incidência 
relativamente maior de clientelismo. Um argumento alternativo, de natureza econômica, para essa mesma relação, é que cidades mais populosas permitem ganhos de escala na provisão de bens e serviços públicos e, neste sentido, desestimulam o particularismo e, por extensão, o clientelismo. Com base em lógica eleitoral, por sua vez, pode-se argumentar também que o monitoramento do voto é mais fácil em cidades pequenas, onde o candidato pode, por exemplo, verificar se o eleitor sinaliza publicamente o seu apoio.

A literatura também sugere haver relação entre a incidência de clientelismo e o grau de competição política, mas com nexo causal mais complexo (Hicken 2011, pp.297-298). Onde o clientelismo tem força, a competição tende a ser menor porque as promessas de entrega de benefícios por parte dos candidatos opositores são menos críveis que as dos ocupantes dos cargos. Por outro lado, nesse mesmo cenário, o acirramento da competição política (por exemplo, em razão de algum choque exógeno) tende a intensificar o clientelismo, pois ao se aumentar o número de candidatos por vaga diminui-se a quantidade esperada de votos de cada um, reduzindo o retorno eleitoral de políticas universalistas e, por extensão, tornando o particularismo mais atraente para os candidatos (Lizzeri \& Persico 2005). Weitz-Shapiro (2012), contudo, argumenta que esse efeito positivo da intensificação da competição é decrescente no nível de desenvolvimento socioeconômico, em razão de os candidatos terem de conquistar votos adicionais entre eleitores de classe média que, por pressuposto, são mais propensos a demandar políticas universalistas. Assim, espera-se que onde a extensão da pobreza seja suficientemente baixa, o aumento da competição tenderá a reduzir, em vez de aumentar, o clientelismo.

Outro fator eleitoral para o qual a literatura chama atenção é a volatilidade. Hicken (2011, p.298) argumenta que quanto mais elevada a volatilidade eleitoral, maior a incerteza dos candidatos sobre se os eleitores honrarão o acordo clientelista, o que diminui o retorno marginal esperado do investimento nessa estratégia de representação, tornando estratégias universalistas mais atraentes para o candidato. Pelo mesmo motivo, é razoável esperar que a volatilidade atenue o efeito da competição política.

Por fim, a literatura sugere que a cultura política importa. Os argumentos são no sentido de que quanto mais alto o valor atribuído pelo indivíduo aos princípios da impessoalidade e do universalismo menor a sua inclinação a adotar práticas clientelistas. A ideologia política e o nível de escolaridade podem ser consideradas proxies para o quanto um indivíduo adere a esses valores. No caso da primeira, a expectativa é que partidários da doutrina liberal ou da socialista sejam menos propensos a adotar práticas clientelistas em razão de estas ideias serem contrárias a políticas particularistas em geral (Kitschelt 2000, pp.864-865). A primeira interpreta essas políticas como uma forma de rent seeking, sendo enfática na denúncia dos seus efeitos negativos sobre a eficiência e o crescimento econômico. A segunda doutrina, por sua vez, interpreta aquelas políticas como privilégios dados indevidamente a grupos e, neste sentido, contrárias ao ideal de uma sociedade baseada no controle coletivo dos recursos. No caso do nível de escolaridade, encontra-se bem documentado na literatura sobre democracia que indivíduos mais instruídos são mais capazes de identificar os benefícios (tipicamente indiretos) de políticas públicas impessoais e universalistas (Almond \& Verba 1989, pp.315-324; Dahl 1989, pp.111112 e pp.306-308).

Portanto, e com base na literatura, espera-se que a incidência do clientelismo na política local seja função de variáveis demográficas, socioeconômicas, políticas e culturais. Para fins de formulação das respectivas hipóteses, pode-se afirmar que se espera que a incidência do clientelismo seja:

H1: Decrescente na quantidade de eleitores do município. 
H2: Crescente na proporção desses eleitores em estado de pobreza.

H3: Crescente na intensificação da competição política, efeito este que é..

H3a: Acentuado pela extensão da pobreza; e

H3b: Atenuado pela incerteza (volatilidade) eleitoral.

H4: Decrescente na volatilidade eleitoral.

H5: Menor entre vereadores com ideologia liberal ou socialista.

H6: Decrescente no nível de escolaridade do vereador.

\section{Desenho da pesquisa}

${ }^{10}$ Identificados com base nos dados municipais do Censo 2000 (IBGE s.d.).
Na definição do desenho da pesquisa, procuramos compatibilizar dois objetivos, a saber: identificar e compreender como os vereadores exercem a representação, especialmente o recurso a práticas clientelistas, e testar estatisticamente se a adoção desta estratégia obedece aos condicionantes apontados pela literatura. Para alcançarmos o primeiro objetivo, achamos mais apropriado entrevistar pessoalmente os vereadores, para que pudéssemos tanto obter informações detalhadas sobre como eles percebem e exercem a vereança quanto minimizar o risco de viés de resposta em questões sensíveis, como sobre a prática do clientelismo. Essa decisão, porém, forçou-nos a restringir severamente a abrangência da amostra, pois nosso orçamento não permitia viagens a municípios espalhados pelo país. O segundo objetivo, por sua vez, exigia uma amostra suficientemente variada tanto de vereadores quanto de municípios, de maneira que os testes estatísticos relativos aos condicionantes individuais (dos vereadores) e ambientais (dos municípios) tivessem força suficiente. A maneira que encontramos para compatibilizar esses dois objetivos foi entrevistar todos os vereadores de uma pequena amostra de municípios, selecionados de acordo com critérios de conveniência e teóricos. A seguir, detalhamos os procedimentos de seleção da amostra e, então, apontamos suas implicações.

Em razão do objetivo de trabalhar com uma amostra pequena de municípios, para minimizar o risco de violação do princípio da homogeneidade restringimos o universo aos predominantemente urbanos (no caso, com pelo menos $65 \%$ dos habitantes em área urbana) e de regiões não metropolitanas do estado de Minas Gerais. As duas primeiras restrições justificam-se por consistirem no tipo modal no país. A opção por Minas Gerais deveu-se aos seus municípios serem em número elevado e apresentarem ampla variedade sociodemográfica. O subconjunto correspondente contém 379 municípios mineiros ${ }^{10}$.

Desse subconjunto, selecionamos uma amostra estratificada, de acordo com os procedimentos sugeridos em Trost (1986). Primeiro, identificamos os fatores ambientais cujos efeitos sobre a incidência do clientelismo parecem ser menos controversos na literatura - no caso, o tamanho da população e a extensão da pobreza. Em seguida, dividimos cada uma dessas variáveis em duas categorias, uma de valor "baixo" e a outra de valor "alto", de forma a se ter quatro combinações de características sociodemográficas para os municípios, a saber: pequeno-pobre, pequeno-rico, grande-pobre e grande-rico. Arbitrariamente, definimos como "pequenos" e "grandes", respectivamente, municípios com até 10 mil habitantes e de 50 mil a 100 mil habitantes. E definimos como "pobres" e "ricos" municípios com pelo menos $40 \%$ e com até $20 \%$ de pessoas em situação de pobreza, respectivamente. Com esse procedimento, procuramos maximizar a variação desses dois fatores ao mesmo tempo em que minimizamos o tamanho da amostra de municípios.

O desenho da amostra também levou em conta o partido político do prefeito eleito em 2008, de maneira a maximizar a chance de a amostra incluir verea- 
${ }^{11}$ Sobre os atributos dos vereadores eleitos em 2008, o sítio eletrônico do Tribunal Superior Eleitoral (TSE) disponibiliza apenas a informação sobre o sexo. Pelo menos nesse item, não há diferença substancial entre a amostra ( $8,9 \%$ de mulheres) e as populações de vereadores brasileiros $(12,5 \%)$ e mineiros $(10,6 \%)$. dores de diferentes inclinações ideológicas. Porém, em razão do grande número de legendas que controlam prefeituras, restringimos a seleção aos seguintes partidos: Partido dos Trabalhadores (PT), Partido do Movimento Democrático Brasileiro (PMDB) e Democratas (DEM). Além de estarem entre as maiores do país, essas legendas cobrem todo o espectro ideológico da política brasileira, da esquerda (PT) à direita (DEM), passando pelo centro (PMDB). Combinando-se as prefeituras controladas por cada um desses partidos com os quatro tipos sociodemográficos anteriormente definidos chega-se, então, a uma amostra total de 12 municípios.

Sem prejuízo, os critérios inicialmente estabelecidos tiveram de ser levemente relaxados tanto por questões de logística do trabalho de campo como para que houvesse pelo menos um município para cada combinação de tamanhopobreza-partido. A Tabela 1 lista os municípios incluídos na amostra, suas respectivas quantidades de vereadores e demais características, de acordo com os critérios de seleção. No Apêndice 1, apresentamos distribuições de algumas características dos vereadores da $\operatorname{amostra}^{11}$.

É importante ter em mente as implicações dessa estratégia de amostragem, para fins de inferência. No caso, o critério de conveniência adotado tem como consequência restringir a população-alvo aos vereadores de municípios urbanos de regiões não metropolitanas do Estado de Minas Gerais. Mesmo para esse subconjunto, a amostra inviabiliza inferências descritivas porque inclui apenas vereadores de municípios com valores extremos de tamanho da população e de nível de pobreza, variáveis estas que, como será demonstrado adiante, afetam a representação política local. Por outro lado, a amostra permite inferências (tentativas) de natureza correlacional, uma vez que (1) a principal condição de validade desse tipo de análise em estudos observacionais é a ausência de seleção pela variável dependente (Smith 1983); (2) pelo menos aparentemente, não há motivo para suspeitar que tal seleção tenha ocorrido neste caso ${ }^{12}$.

Por fim, sobre o trabalho de campo nos 12 municípios, ele foi realizado em duas etapas, sendo a primeira entre julho e agosto de 2010 (quatro municípios), e a segunda entre maio e dezembro de 2011. Ao todo, foram entrevistados 112

Tabela 1 - Amostra de municípios

\begin{tabular}{|c|c|c|c|c|c|}
\hline Município $^{I}$ & População & Pobres (\%) & Tipo $^{I I}$ & Partido do prefeito ${ }^{\mathrm{III}}$ & N. de vereadores \\
\hline Bonfinópolis de Minas & 6.443 & 48,6 & $\mathrm{PP}$ & PT & 09 \\
\hline Conceição dos Ouros & 8.929 & 22,3 & PR & DEM & 09 \\
\hline Diamantina & 44.259 & 40,2 & GP & PMDB & 09 \\
\hline Formiga & 62.907 & 21,1 & GR & PT & 10 \\
\hline Ituiutaba & 89.091 & 21,8 & GR & PMDB & 10 \\
\hline Janaúba & 61.651 & 50,2 & GP & PT & 10 \\
\hline Madre de Deus de Minas & 4.734 & 43,0 & PP & PMDB & 09 \\
\hline Monsenhor Paulo & 7.615 & 18,6 & PR & PMDB & 09 \\
\hline Pains & 7.798 & 20,61 & PR & PT & 09 \\
\hline Pirapora & 50.300 & 41,37 & GP & DEM & 10 \\
\hline São João do Oriente & 8.492 & 49,6 & PP & DEM & 09 \\
\hline São Sebastião do Paraíso & 58.335 & 12,8 & GR & DEM & 10 \\
\hline
\end{tabular}

Fontes: IBGE (s.d.), IPEA (s.d.) e TSE (s.d.).

${ }^{\mathrm{I}}$ Municípios de Minas Gerais.

${ }^{\text {II }} \mathrm{PP}=$ pequeno-pobre, $\mathrm{PR}=$ pequeno-rico, $\mathrm{GP}=$ grande-pobre, $\mathrm{e} \mathrm{GR}=$ grande-rico.

${ }^{\text {III }}$ Eleitos em 2008. 
12 Permanece, no entanto, a questão da validade do uso do teste de significância em amostras não probabilísticas, tal como a utilizada neste estudo. Mas esse é um problema geral (cf. Collier, Brady \& Seawright 2010, p.167).

\section{Análise descritiva}

vereadores que exerceram mandato durante a legislatura 2009-2013, sempre pelos próprios autores e quase sempre in loco. Tendo-se em mente a expectativa de cumprimento das funções formais da vereança (legislar e fiscalizar), por um lado, e a conotação depreciativa de atividades particularistas, por outro, nas entrevistas não se utilizou explicitamente dos conceitos de "particularismo", "assistencialismo" e "clientelismo", nem se contrapôs o exercício de atividades particularistas às funções formais da vereança. Outro cuidado que tivemos para minimizar o risco de viés de resposta foi garantir aos vereadores o anonimato da fonte ${ }^{13}$.

Nesta seção, utilizamos o conteúdo das entrevistas para, primeiro, descrever e analisar como os vereadores percebem e exercem a representação política e, em seguida, classificar cada vereador de acordo com a sua principal estratégia de representação.

\section{IV.1. Percepção sobre representação}

${ }^{13}$ Com exceção de duas, todas as entrevistas foram gravadas em áudio, com duração média de 50 minutos. Apenas um vereador não concordou em participar da pesquisa. Sete entrevistas foram realizadas por telefone, em razão da indisponibilidade do vereador quando da nossa visita ao município. Nas transcrições citadas neste artigo, identificamos o entrevistado por meio de número aleatório. As transcrições e o questionário podem ser obtidos mediante solicitação aos autores.

14 Kappa mede a concordância
Para identificar como os vereadores percebem a representação política, perguntamos-lhes sobre as principais demandas dos seus eleitores e sobre o que eles gostariam de fazer no exercício da vereança. A primeira pergunta foi: "No seu entender, quais são as principais coisas que os seus eleitores querem que o(a) senhor(a) faça como vereador(a)?" Imediatamente em seguida, perguntamos se o vereador gostaria de fazer algo diferente do desejado pelos seus eleitores e, se positivo, o quê. As respostas a essas duas perguntas, todas espontâneas, permitiram categorização em dois grandes grupos: (a) as diretamente relacionadas a pelo menos uma das funções formais da vereança (legislar e fiscalizar) e (b) outras, relacionadas ao atendimento de pedidos dos eleitores. Estas, por sua vez, foram classificadas de acordo com a natureza do pedido, se coletivo ou particular. No primeiro caso, incluem-se pedidos de grupos, como moradores de um bairro, membros de uma associação etc. No segundo, pedidos individuais como ajuda para tratamento de saúde, para a realização de viagens e para a aquisição de material de construção. Em suma, as atividades mencionadas foram classificadas em três categorias, a saber: exercício formal (legislar ou fiscalizar), atendimento de pedidos coletivos e atendimento de pedidos particulares.

O Gráfico 1 apresenta as frequências das respostas, tal como classificadas, sobre as principais atividades demandadas e as que os vereadores desejam exercer. Como vários entrevistados mencionaram mais de um tipo de atividade, as frequências relativas de cada conjunto de respostas não somam $100 \%$. A demanda apontada com maior frequência foi o atendimento de pedidos coletivos $(55,4 \%)$. O exercício da função formal aparece em distante segundo lugar $(39,3 \%)$, sendo seguida de perto pelo atendimento de pedidos particulares $(34,8 \%)$. Essa distribuição difere substancialmente da observada para as respostas sobre qual atividade o vereador deseja exercer. Nesse caso, as atividades formais da vereança despontam em primeiro lugar e com frequência muito maior (58\%), seguida de perto pelo atendimento de pedidos coletivos (50\%) e, por fim, com frequência bem menor, o atendimento de pedidos particulares $(21,4 \%)$.

A Tabela 2 apresenta, para cada uma daquelas três atividades, a porcentagem de vereadores que desejam exercê-la, condicionada a se a atividade é uma das principais demandas dos seus eleitores. Ela permite avaliar o grau de concordância entre essas duas dimensões, que medimos por meio de Kappa $(k)^{14}$. Nota-se substancial concordância entre a percepção dos vereadores sobre 
entre as categorias de duas variáveis categóricas, descontando o acaso. A medida varia entre 0 e 1 , com valores maiores expressando maior concordância.
Gráfico 1 - Atividade mais demandada pelos eleitores e atividade que o vereador deseja exercer $(\%)$

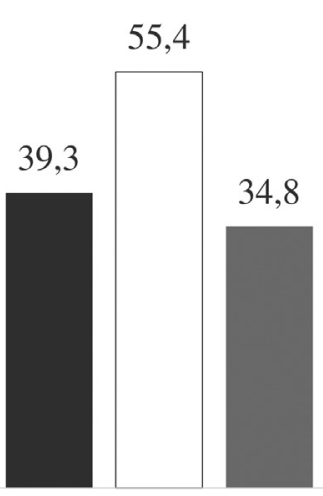

Eleitores demandam

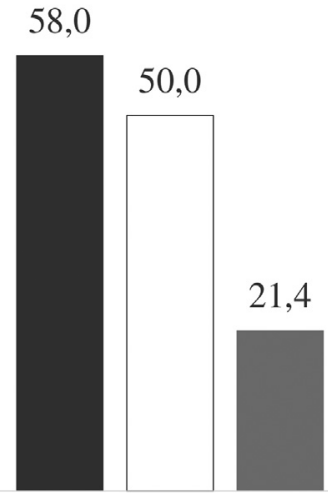

Vereador deseja
- Exercer função formal

$\square$ Atender pedido coletivo

- Atender pedido particular

Fonte: Os autores.

Nota: $\mathrm{N}=112$.

Tabela 2 - Relação entre a demanda pela atividade e o desejo do vereador de exercê-la, por tipo de atividade

\begin{tabular}{|c|c|c|c|c|c|c|}
\hline & \multicolumn{2}{|c|}{ Atividade formal } & \multicolumn{2}{|c|}{$\begin{array}{c}\text { Atendimento de pedido } \\
\text { coletivo }\end{array}$} & \multicolumn{2}{|c|}{$\begin{array}{c}\text { Atendimento de pedido } \\
\text { particular }\end{array}$} \\
\hline & $\begin{array}{l}\text { Eleitores não } \\
\text { demandam }\end{array}$ & $\begin{array}{c}\text { Eleitores } \\
\text { demandam }\end{array}$ & $\begin{array}{l}\text { Eleitores não } \\
\text { demandam }\end{array}$ & $\begin{array}{c}\text { Eleitores } \\
\text { demandam }\end{array}$ & $\begin{array}{l}\text { Eleitores não } \\
\text { demandam }\end{array}$ & $\begin{array}{c}\text { Eleitores } \\
\text { demandam }\end{array}$ \\
\hline $\begin{array}{l}\text { Vereador não } \\
\text { deseja exercer }\end{array}$ & $47(69,1 \%)$ & $0(0 \%)$ & $46(92,0 \%)$ & $10(16,1 \%)$ & $71(97,3 \%)$ & $17(43,6 \%)$ \\
\hline $\begin{array}{l}\text { Vereador } \\
\text { deseja exercer }\end{array}$ & $21(30,9 \%)$ & $44(100 \%)$ & $4(8,0 \%)$ & $52(83,9 \%)$ & $2(2,7 \%)$ & $22(56,4 \%)$ \\
\hline Total & $68(100 \%)$ & $44(100 \%)$ & $50(100 \%)$ & $62(100 \%)$ & $73(100 \%)$ & $39(100 \%)$ \\
\hline Kappa $(k)$ & \multicolumn{2}{|c|}{0,64} & \multicolumn{2}{|c|}{0,75} & \multicolumn{2}{|c|}{0,59} \\
\hline
\end{tabular}

Fonte: Os autores.

o que é demandado e o que eles desejam fazer, principalmente no que diz respeito ao atendimento de pedidos coletivos $(k=0,75)$. Na verdade, as únicas discordâncias que chamam a atenção são que: (1) quase um terço $(30,9 \%)$ dos vereadores que não mencionaram funções formais entre as atividades mais demandadas pelos seus eleitores desejam exercer tais atividades; (2) 43,6\% dos vereadores que mencionaram o atendimento de pedidos particulares como uma das principais demandas dos seus eleitores não desejam exercer esta atividade. Essa assimetria indica que, para um número significativo de vereadores, existe conflito entre o exercício das funções formais da vereança e as demandas particularistas dos eleitores.

A título de ilustração desse conflito, transcrevemos as seguintes passagens dos depoimentos de dois vereadores, o primeiro de um município pequenopobre e o outro, de um grande-rico: 


\begin{abstract}
"Você sabe muito bem qual é o papel do vereador: defender os melhores projetos do município, fiscalizar e acompanhar a administração. Mas, infelizmente, aqui é o contrário. [...] Por exemplo, se bater uma pessoa na minha porta, principalmente com esse [pedido] de transporte, se você não atender ele, pelo lugar ser muito pequenininho, meu Deus! Assim que ele vira as costas lá, ele já sai para a rua [dizendo]: 'tá vendo, votei nesse cara, precisei dele agora, não pode me ajudar’. Então, volto a dizer, é a política de assistencialismo, que não é o muito correto. A gente faz porque a gente está dentro da coisa, praticamente você se sente na obrigação, você é obrigado a fazer. Ou você faz ou você queima o seu filme" (Entrevistado n. 588).

"Eu acredito que além de fazer uma boa fiscalização, isso é uma função privilegiada do vereador, para ver como o dinheiro está sendo gasto. [...] A política em si de vereador, aqui, apesar de ser uma cidade grande, é de costumes bem provincianos ainda. Aqui é a política do toma lá, dá cá. Aquela política de favores. [...] São manias mesmo, tradição na cidade. [Acha-se] que o vereador tem que fazer de tudo: pagar conta de água, pagar conta de luz, arrumar transporte, arrumar cesta básica, remédio, conta de telefone. Enfim, tudo que uma família necessita, acha que o vereador é obrigado a ajudar" (Entrevistado n. 456).
\end{abstract}

\title{
IV.2. Exercício da representação
}

${ }^{15}$ Dentre as funções formais, a fiscalização foi mencionada com frequência muito maior. Isso é natural, uma vez que, se por um lado os vereadores pouco têm sobre o que legislar, por outro, podem observar de perto as ações da prefeitura.

${ }^{16}$ Provavelmente, isso resulta em boa medida de o tempo tomado por cada atividade depender das condições para a sua execução, e não apenas da dedicação do vereador. Notamos, por exemplo, que nos municípios pequenos a carga de trabalho legislativo é baixa, mas alguns vereadores
Passamos agora à questão de como a vereança é exercida no dia-a-dia. Para identificar as principais atividades políticas dos vereadores, perguntamos quais tomavam mais tempo da vereança. Atividades formais (legislar ou fiscalizar) foram mencionadas espontaneamente por metade $(49,1 \%)$ dos vereadores da $\operatorname{amostra}^{15}$. O atendimento de pedidos particulares foi mencionado por pouco mais de um terço (36\%), seguido pelo atendimento de pedidos coletivos $(30,1 \%)$. O passo seguinte foi verificar a concordância entre as atividades às quais o vereador dedica mais tempo e aquelas que, na sua percepção, são as mais demandadas pelos seus eleitores. Os valores $k$ da Tabela 3 mostram que o grau de concordância é apenas moderado e substancialmente menor que os da tabela anterior ${ }^{16}$. Nesse caso, a evidência de conflito entre exercício formal e demandas eleitorais particularistas é tênue. Não obstante, é interessante notar que quase um terço $(29,4 \%)$ dos vereadores que não mencionaram demanda pelo exercício de funções formais afirmaram que esta atividade está entre as que mais tomam seu tempo.

$\mathrm{O}$ atendimento de pedidos coletivos, geralmente relacionados à infraestrutura do município, somente pode ser realizado mobilizando-se verbas públicas, do próprio município ou via transferência de outros níveis de governo. Vereadores para os quais essa atividade está entre as que mais tomam tempo

Tabela 3 - Relação entre a demanda pela atividade e o tempo que o vereador dedica a ela, por tipo de atividade

\begin{tabular}{lcccccccc}
\hline & \multicolumn{2}{c}{ Atividade formal } & & \multicolumn{2}{c}{$\begin{array}{c}\text { Atendimento de pedido } \\
\text { coletivo }\end{array}$} & & \multicolumn{2}{c}{$\begin{array}{c}\text { Atendimento de pedido } \\
\text { particular }\end{array}$} \\
\cline { 2 - 3 } & $\begin{array}{c}\text { Eleitores não } \\
\text { demandam }\end{array}$ & $\begin{array}{c}\text { Eleitores } \\
\text { demandam }\end{array}$ & & $\begin{array}{c}\text { Eleitores não } \\
\text { demandam }\end{array}$ & $\begin{array}{c}\text { Eleitores } \\
\text { demandam }\end{array}$ & & $\begin{array}{c}\text { Eleitores não } \\
\text { demandam }\end{array}$ & $\begin{array}{c}\text { Eleitores } \\
\text { demandam }\end{array}$ \\
\hline $\begin{array}{l}\text { Não é uma das que } \\
\text { mais tomam tempo }\end{array}$ & $48(70,6 \%)$ & $9(20,5 \%)$ & & $47(94,0 \%)$ & $30(49,2 \%)$ & & $60(83,3 \%)$ & $11(28,2 \%)$ \\
$\begin{array}{l}\text { É uma das que } \\
\text { mais tomam tempo }\end{array}$ & $20(29,4 \%)$ & $35(79,6 \%)$ & & $3(6,0 \%)$ & $31(50,8 \%)$ & & $12(16,7 \%)$ & $28(71,8 \%)$ \\
Total & $68(100 \%)$ & $44(100 \%)$ & & $51(100 \%)$ & $61(100 \%)$ & & $72(100 \%)$ & $39(100 \%)$ \\
\hline Kappa $(k)$ & \multicolumn{2}{c}{0,48} & & \multicolumn{2}{c}{0,43} & & \multicolumn{2}{c}{0,55} \\
\hline
\end{tabular}

Fonte: Os autores. 
dispendem muito tempo transportando eleitores para municípios grandes, geralmente para atendimento hospitalar. enfatizaram a sua "busca por recursos", inclusive além dos limites do município. Ou seja, além de fazerem indicações legislativas ao prefeito, eles costumam "correr atrás" de verbas, acionando, para tanto, suas redes de relacionamento político em outros níveis de governo. Atuam, assim, como verdadeiros captadores de recursos.

A mobilização de recursos públicos também é utilizada no atendimento sistemático de pedidos particulares. Quase um quarto dos vereadores $(23,6 \%)$ afirmou que atende esses pedidos de maneira sistemática utilizando principalmente sua influência na prefeitura e, eventualmente, na política estadual. Parcela semelhante $(27,3 \%)$ afirmou que recorre principalmente a recursos privados, próprios ou oriundos de parcerias com comerciantes e profissionais liberais, para o atendimento daqueles pedidos. Por exemplo, no caso de pedidos relativos à saúde, que são muito frequentes, alguns vereadores mantêm parcerias com farmácias, para a compra de remédios com desconto, e até com clínicas e médicos, para a realização de exames e consultas a preços menores. Outros $18,2 \%$ disseram que recorrem tanto a recursos públicos quanto privados.

Por fim, pouco menos de um terço $(30,9 \%)$ afirmou que não atende pedidos particulares de maneira sistemática, preferindo encaminhá-los aos órgãos públicos responsáveis. Alguns desses vereadores mencionaram que podem até interceder em favor do pedido, mas sempre dentro dos limites da prestação do serviço público. O que distingue esse simples encaminhamento ao serviço público do atendimento com recursos públicos é que, no segundo caso, o vereador mobiliza sistematicamente sua rede de relacionamentos políticos. $\mathrm{Ou}$ seja, o atendimento com mobilização de recursos públicos depende mais da influência do vereador do que da disponibilidade do serviço público. Os dois depoimentos que transcrevemos a seguir ilustram de maneira exemplar os respectivos casos:

"[Recebo] muitos pedidos de exame [...] e sempre procuro a parte de procurar a assistência social. [...] Aquele negócio 'toma', isso daí eu não faço. Sempre que me procuram, eu procuro alguma entidade que, às vezes, tem alguma verba que possa, ou então procuro a assistência social da prefeitura [...]. Sempre procuro encaminhar, não 'toma aqui, vai e faz'. [Meu padrão é] Encaminhar e resolver através do serviço público” (Entrevista n. 839).

"Procuro um meio [de atender o pedido particular]. Por exemplo, não consigo dessa forma aqui, aí vou para o setor de saúde, vou no secretário de saúde. O setor de obra, vou no secretário de obra. [Tem setor que] vou direto no prefeito. [...] Vou no presidente da Câmara, pra ajudar. Procuro ajuda: 'Doutor, tem uma família com problema assim, uma doença bem séria, uma coisa qualquer, eu preciso de uma ajuda do senhor para liberar'. Aí, eu ligo pra BH [Belo Horizonte], ligo pra um canto e pro outro. [...] Por exemplo, eu ligo pra Assembleia pedindo a força de um deputado" (Entrevistado n. 897).

IV.3. Três tipos de representantes

Tendo em vista os achados anteriores, classificamos cada vereador da amostra como um de três tipos ideais de representantes, que denominamos "assistencialista", "captador" e "legislador". O assistencialista, e somente ele, dedica grande parte do seu tempo e esforço ao atendimento sistemático de pedidos particulares dos eleitores. O captador dedica-se mais ao atendimento de pedidos coletivos, geralmente voltados para ações de infraestrutura no município. Como mencionamos anteriormente, essa atividade requer a busca (ou captação) de verbas públicas, junto ao executivo municipal ou em outras esferas de governo. O legislador, por fim, dedica-se principalmente ao exercício de pelo menos uma das funções formais da vereança, que são legislar e fiscalizar o executivo local. 
${ }^{17}$ Marcamos sete casos como duvidosos. Retornamos a essa questão na seção 5.3 , na qual avaliamos a robustez dos resultados.
Consideramos esses tipos "ideais" porque a grande maioria dos vereadores exerce todas essas atividades, umas mais, outras menos. Se, por um lado, existem os que veem conflito entre o atendimento de pedidos, principalmente os particulares, e o exercício das funções formais, pelo outro, há os que entendem que essas atividades se complementam. Não obstante, exceto em poucos casos, foi possível identificar uma atividade à qual o vereador confere maior ênfase de fato ${ }^{17}$. Os depoimentos transcritos a seguir, que correspondem a cada um desses tipos, podem ser considerados exemplares:

Assistencialista. "O que consome mais tempo é o atendimento dos pedidos dos eleitores. [...] Os meus eleitores são as pessoas mais carentes. O principal que o pessoal cobra da gente é o trabalho social. [...] A gente tem aqueles eleitores mais fiéis. Então, comecei a ajudar um pouco, na assistência social. [...] Meu tema mais é saúde, desde o primeiro mandato. Se Deus quiser, a gente vai continuar com isso o resto do mandato. [...] Tenho umas parcerias com médicos. E tenho aqui com a Câmara, que é o centro odontológico. Tenho parceria com outros médicos aqui na região e também com um deputado que a gente apoia. A gente tem pareceria também em [nome de outra cidade]. Então a gente repassa para o eleitor quando ele precisa. [...] A gente recebe esses pedidos de bairro, iluminação de rua, esses pedidos corriqueiros de calçamento. A gente faz os pedidos, mas, às vezes, não é atendido. Obra a gente faz e, às vezes, não aparece seu nome. [...] Então, quando é você mesmo quem faz - nesse foco que falei, na área de saúde - aparece seu nome" (entrevistado n. 965).

Captador. "Praticamente todo o meu tempo é para atender pedido de eleitor. [...] Minha atuação não é pro eleitor aqui do botijão de gás, da cesta básica. Meu eleitor é mais consciente. É uma associação que me pede para interceder junto ao governo do estado para liberar recursos; a polícia militar que pede para fazer um projeto de lei em nível estadual ou federal para trazer viaturas; o funcionário público que precisa utilizar da influência nossa [na prefeitura] para agilizar um processo para sua categoria; uma diretora que quer a liberação de uma reforma de escola; no DNIT, a liberação de um mata-burro. [...] Meus eleitores esperam isso: que eu vá trazer recursos, benefícios pro município" (Entrevistado n. 166).

Legislador. "A maioria dos meus eleitores, eles querem atividade parlamentar, cobrança do prefeito. [...] A atividade que mais consome o meu tempo é aquela atividade de estar aqui, na Câmara, porque eu sou muito presente na questão de comissão permanente. Sou muito de estar pedindo informações ao poder jurídico nosso, ao advogado nosso, à assessoria parlamentar, para que eu esteja inteirado do que eu estou votando. [...] Reivindicar água, luz, esgoto, reivindicar tudo aquilo que a comunidade vem e traz para a gente, eu acho que eu tenho que levar para o plenário [da Câmara]" (Entrevistado n. 75).

A classificação foi feita pelos próprios autores, em comum acordo e com base na interpretação dos dados semiestruturados das entrevistas abertas, seguindo basicamente o método delineado em Campbell et al. (2013). O conhecimento do tema e a condição privilegiada de entrevistador contribuíram decisivamente para a interpretação e, por conseguinte, para que chegássemos a uma classificação confiável. A regra de classificação adotada foi a seguinte: se o vereador se dedica ao atendimento sistemático de pedidos particulares, então ele é assistencialista, independentemente de quanto tenha afirmado que se dedica às outras atividades; caso contrário, ele é considerado captador se a sua dedicação está direcionada principalmente ao atendimento de pedidos coletivos; e legislador, se voltada principalmente para o exercício de função formal da vereança.

Seguindo esses critérios, encontramos que o tipo assistencialista é o de maior incidência na amostra, compreendendo $40,2 \%$ dos vereadores. Em segundo lugar, e bastante próximo, aparece o tipo legislador, com 35,7\%. Em último, com $24,1 \%$, está o tipo captador. Embora não seja passível de generalização, essa distribuição aponta para cenário mais otimista da representação local, segundo o qual parte substancial dos vereadores dedica-se às funções 
formais da vereança e o assistencialismo, embora estratégia dominante, não é universal.

Esses três tipos correspondem, em boa medida, às três dimensões de atividade mapeadas por Joffre Neto (2003): "político-institucional" (nosso legislador), "comunitária" (captador) e "pessoal" (assistencialista). Com base em declarações de uma amostra nacional de 112 vereadores, obtidas por meio de sondagem postal, o autor estima incidência bem menor do que seriam os nossos legisladores $(10,7 \%)$, bem maior de assistencialistas $(60,7 \%)$ e incidência similar de captadores $(26,8 \%)$. Embora a validade dessas estimativas possa ser questionada em razão de a amostra sobrerrepresentar severamente presidentes de câmaras e não controlar por autosseleção, uma provável explicação para as diferenças entre os resultados de Joffre Neto e os nossos é a sua decisão de incluir, entre as atividades assistencialistas, o encaminhamento de pedidos particulares a órgãos públicos (Joffre Neto 2003, p.143). Tal como argumentamos anteriormente, o encaminhamento feito por parcela substancial dos vereadores da nossa amostra não tem conotação de uso de influência ou poder pessoal para atender o pedido. Ao contrário, visa meramente orientar a demanda do cidadão ao órgão prestador do serviço. Por isso, entendemos que esses casos não têm conotação assistencialista. Suspeitamos, portanto, que a interpretação dada por Joffre Neto ao encaminhamento de pedidos tenha inflado sua estimativa de assistencialistas e comprimido a de legisladores.

Conceitualmente, a nosso ver, o assistencialista e o legislador são os tipos que mais se aproximam dos padrões de representação clientelista e universalista, respectivamente. É bem verdade que nossos dados não permitem avaliar se o assistencialismo é motivado pelo voto, como pressupõe o conceito de clientelismo, nem se as funções formais são exercidas segundo a lógica universalista. Note-se, porém, que a conotação negativa do uso instrumental do assistencialismo dificulta a confirmação daquele pressuposto com base em depoimentos de parlamentares e que o vereador pouco ou nada pode fazer por meio da atuação legislativa ou fiscalizadora para atender a demandas particularistas.

Por outro lado, não está claro se (e onde) o tipo captador pode ser posicionado no continuиm particularismo-universalismo. Se, por um lado, a sua estratégia de representação não privilegia o atendimento sistemático de pedidos particulares, por outro, ela também não enfatiza o exercício sistemático das funções formais da vereança. Diante dessa indefinição conceitual, optamos por "ouvir" o que os dados têm a dizer. A maneira como fizemos isso é explicada em detalhe na próxima seção.

\section{Análise de regressão}

Nesta seção, recorremos a análise de regressão multivariada para testar as hipóteses sobre os condicionantes da incidência do clientelismo entre os vereadores, listadas ao fim da segunda seção.

\section{V.1. Dados e métodos}

\footnotetext{
${ }^{18}$ Com base na abordagem do ator racional, pode-se conceber a estratégia de representação como comportamento de equilíbrio, resultante, por um lado, da escolha do vereador sobre
}

A variável dependente é o tipo de vereador - se assistencialista, captador ou legislador. Nossa premissa é que esses tipos correspondem a escolhas dos vereadores quanto à sua estratégia de representação ${ }^{18}$, e que o assistencialista e 0 legislador pertencem a uma mesma dimensão, que contrapõe particularismo a universalismo. Contudo, não temos expectativa pré-definida sobre se o captador também pode ser localizado nessa dimensão, como tipo intermediário, ou, em vez disso, se ele é um tipo qualitativamente distinto. Avaliamos essas possibilidades com base exclusivamente nos dados. 
como representar e, por outro, das escolhas dos eleitores sobre em qual tipo de vereador votar. Isso não requer o pressuposto de que todo vereador escolhe, a cada eleição, o padrão de representação que maximiza a sua chance de ser eleito. Apenas que os eleitores votam nos tipos mais adequados às suas preferências e necessidades e que candidatos que não levam em conta o comportamento dos eleitores têm maior risco de não serem eleitos.

19 As estimações foram realizadas por meio do programa Stata 11. O banco de dados e as rotinas de estimação podem ser obtidos mediante solicitação aos autores.
20 Agradecemos a um parecerista anônimo por apontar para a necessidade de se usar uma medida de variação, e não de nível, da competição política, para que o teste da hipótese fosse adequado.

${ }^{21}$ Rae (1995, p.69) define o limiar de representação como a fração de votos que assegura a um partido pelo menos uma cadeira, independentemente da distribuição dos votos entre os demais partidos.

Matematicamente, pode ser expresso como $1 /(\mathrm{m}+1)$, onde $m$ é o número de cadeiras em disputa (magnitude do distrito).
Em razão da natureza categórica da variável dependente e das dúvidas a respeito da natureza do tipo captador, testamos a adequação de dois modelos estatísticos. O primeiro é o Probit Ordinal, que pressupõe a existência de ordem entre as categorias da variável, o que permite avaliar se o captador pode ser considerado um tipo intermediário. O segundo modelo é o Probit Multinomial, que não pressupõe qualquer ordem entre as categorias e, assim, permite avaliar se o captador é qualitativamente distinto dos outros dois. Para o teste, estimamos os modelos com as mesmas variáveis independentes, os mesmos dados e considerando a estrutura de cluster por municípios. Esse último aspecto permite levar em conta provável correlação entre as observações de cada município ${ }^{19}$.

Para os condicionantes do clientelismo, identificados pelas hipóteses listadas anteriormente, são utilizadas as seguintes medidas:

1. Município grande (H1). Indicador do tamanho do município, que assume valor 1 se ele tem número "grande" de habitantes, como definido anteriormente (ver Tabela 1), e 0 se não.

2. Município rico (H2). Indicador da condição socioeconômica do município, que assume valor 1 se ele tem parcela "pequena" de pessoas em estado de pobreza, como definido anteriormente, e 0 se não.

3. Aumento da competição política (H3). Para medir o aumento da competição política lançamos mão do fato de que, em 2004, por meio da Resolução n. 21.702, o TSE reduziu o número de vagas de várias câmaras municipais. Essa redução equivaleu a um choque exógeno sobre a competição política local, acirrando-a. Parece-nos razoável pressupor que as eventuais implicações desse choque para a representação local tenham se feito sentir também nas eleições de 2008, quando foram eleitos os vereadores da amostra. Com essa estratégia de mensuração, elimina-se qualquer efeito reverso da variável dependente, a incidência de clientelismo, sobre a competição, livrando-se o teste de hipótese do problema de endogeneidade ${ }^{20}$.

Utilizou-se como medida de aumento da competição política a razão entre os limiares (thresholds) $)^{21}$ de representação definidos de acordo com a quantidade de cadeiras em disputa $(\mathrm{m})$, antes $\left(\mathrm{m}_{0}\right)$ e depois $\left(\mathrm{m}_{1}\right)$ da decisão do TSE, conforme a seguinte fórmula: $1-\left(\mathrm{m}_{1}+1\right) /\left(\mathrm{m}_{0}+1\right)$. Essa medida tem valor zero quando a quantidade de cadeiras permanece a mesma, valores positivos (mais competição) quando $\mathrm{m}_{1}<\mathrm{m}_{0}$ e valores negativos (menos competição) quanto $\mathrm{m}_{1}>\mathrm{m}_{0}$. Na amostra, a maior redução relativa de cadeiras foi de 17 para 10, e a menor, de 11 para 9. Em três municípios não houve alteração.

Para testar se o efeito do aumento da competição política é condicionado pela extensão da pobreza (H3a) e pela volatilidade eleitoral (H3b), criamos termos multiplicativos daquela variável com cada uma dessas.

4. Volatilidade eleitoral (H4). Volatilidade dos votos dados aos candidatos a vereador do município, calculada com base nos resultados das eleições de 2008 e 2004 (TSE s.d.), conforme a fórmula $1 / 2 \times\left|\sum \mathrm{v}_{i 2008}-\mathrm{v}_{i 2004}\right|$, onde $\mathrm{v}_{i}$ é a fração dos votos válidos do candidato $i$. Volatilidade tem mínimo teórico igual a 0 (todos os candidatos que disputaram a primeira eleição disputaram a seguinte, e cada um recebeu a mesma quantidade de votos que na primeira) e máximo teórico igual a 1 (nenhum dos candidatos que disputou a primeira eleição disputou a seguinte). A justificativa para essa operacionalização é que, por definição, o eleitor que não honra o acordo clientelista muda seu voto entre uma eleição e outra. Assim, quanto maior a parcela desses eleitores, maior a volatilidade eleitoral.

5. Partido de esquerda e partido de direita (H5). Indicadores da orientação ideológica do partido ao qual o vereador declarou estar filiado, na ocasião da entrevista. A primeira variável assume valor 1 para os vereadores da amostra filiados ao PT, Partido Comunista do Brasil (PCdoB), Partido Socialista 
${ }^{22}$ Os demais partidos da amostra, classificados como de centro, são: Partido do Movimento Democrático Brasileiro (PMDB); Partido da República (PR); Partido Republicano Brasileiro (PRB); Partido Social Cristão (PSC); Partido Social Democrático (PSD); Partido da Social Democracia Brasileira (PSDB); Partido Social Liberal (PSL); Partido Trabalhista Brasileiro (PTB); Partido Trabalhista Cristão (PTC); Partido Verde (PV). A classificação foi baseada nas estimativas de Power e Zucco (2009) para os partidos da Câmara dos Deputados.

23 Note-se, contudo, a plausibilidade de causação reversa, pois é razoável supor que vereadores do tipo legislador têm mais incentivos para investir na capacidade da Câmara Municipal.

\section{V.2. Resultados}

${ }^{24}$ Agradecemos a um parecerista anônimo por sugerir a inclusão dessa variável.
Brasileiro (PSB), Partido da Mobilização Nacional (PMN), Partido Democrático Trabalhista (PDT) ou ao Partido Popular Socialista (PPS), e 0 para os demais partidos. A segunda variável assume valor 1 para os vereadores filiados ao DEM ou ao Partido Progressista (PP), e 0 para os demais ${ }^{22}$. Utilizamos a classificação ideológica do partido do vereador em razão de não termos conseguido obter medida mais adequada para sua ideologia. Nas entrevistas, a maior parte dos vereadores teve dificuldade em se posicionar no eixo esquerda-direita e constatamos vários indícios de que divisões ideológicas são pouco relevantes na política local. Por isso, os resultados relativos a essas variáveis devem ser interpretados com cautela.

6. Escolaridade (H6). Quantidade mínima de anos de estudo exigida até a última série ou nível de instrução que o vereador declarou ter completado.

Além dessas variáveis, para as quais existem expectativas teóricas, incluímos também duas outras, a saber, a capacidade institucional da câmara e a antiguidade do vereador. A variável capacidade do legislativo é um índice aditivo de quatro indicadores do Censo do Legislativo 2005 (Brasil s.d.), que informam a existência, na câmara local, dos seguintes itens: computadores (codificada como 0, se existem de um a cinco computadores; 1 se existem de seis a dez; e 2, se mais de dez); sistema de processo legislativo (1 se existe, 0 se não); sistema de atividade parlamentar (idem); e sistema administrativo (idem). A hipótese ad hoc que motivou a inclusão dessa variável é que legislativos com maior capacidade institucional favorecem a adoção de estratégias de representação mais formais e, assim, aumentam a probabilidade de o vereador ser do tipo legislador ${ }^{23}$. A variável tempo de vereança (em anos) visa capturar eventual efeito positivo da antiguidade do vereador sobre a probabilidade de ser do tipo assistencialista, sendo sua inclusão motivada por achados empíricos recentes, que sugerem que o clientelismo está em declínio (Fried 2012; Montero 2012) ${ }^{24}$. A Tabela 4 apresenta as estatísticas descritivas usuais das variáveis independentes.

Os resultados (não reportados) dos testes da adequação dos pressupostos dos modelos aos dados levam à seleção do modelo multinomial, em detrimento do ordinal. O pressuposto de que os coeficientes não variam entre categorias da variável dependente (regressão paralela) é rejeitado para município rico e não há evidência de violação do pressuposto de que todas as categorias são distintas entre si (isto é, que nenhuma pode ser combinada com outra) ${ }^{25}$.

Tabela 4 - Descritivas das variáveis independentes

\begin{tabular}{|c|c|c|c|c|c|}
\hline & Média & Mediana & D. padrão & Mínimo & Máximo \\
\hline Município grande & 0,518 & 1 & 0,502 & 0 & 1 \\
\hline Município rico & 0,509 & 1 & 0,502 & 0 & 1 \\
\hline Crescimento da competição & 0,214 & 0,313 & 0,141 & 0 & 0,389 \\
\hline Volatilidade eleitoral & 0,553 & 0,545 & 0,066 & 0,443 & 0,693 \\
\hline Partido de esquerda & 0,223 & 0 & 0,418 & 0 & 1 \\
\hline Partido de direita & 0,196 & 0 & 0,399 & 0 & 1 \\
\hline Escolaridade & 10,5 & 11 & 4,11 & 3 & 17 \\
\hline Capacidade do legislativo & 2,71 & 3 & 1,76 & 0 & 5 \\
\hline Tempo de vereança & 5,76 & 2,5 & 5,0 & 1 & 24 \\
\hline
\end{tabular}

Fontes: Os autores, a partir de TSE (s.d.), SF/SINTER (s.d.) e do banco de dados da pesquisa.

Nota: $\mathrm{N}=112$. 
${ }^{25}$ O teste Brant da versão logit do modelo ordinal permite rejeitar o pressuposto de regressão paralela com confiança superior a $95 \%$. O teste generalizado de Hausman permite rejeitar, com mais de 99\% de confiança, a combinação de categorias. Para esse teste, utilizou-se o método seemingly unrelated estimation, comparando-se as
A Tabela 5 reporta as estimativas probit multinomial, com o tipo legislador como categoria de referência, e os valores absolutos das respectivas estatísticas z, calculadas utilizando-se o erro padrão sanduíche com clusters definidos por município. Para testar se o efeito do crescimento da competição política é moderado pela volatilidade ou pela extensão da pobreza, ao modelo básico (modelo 1) acrescentamos separadamente a interação daquela variável com volatilidade (modelo 2) e com município rico (modelo 3). Note-se, contudo, que o número muito reduzido de observações por município inviabilizou a inclusão de efeitos fixos para essas unidades, o que impõe cautela na interpretação dos

Tabela 5 - Estimativas probit multinomial do tipo de vereador

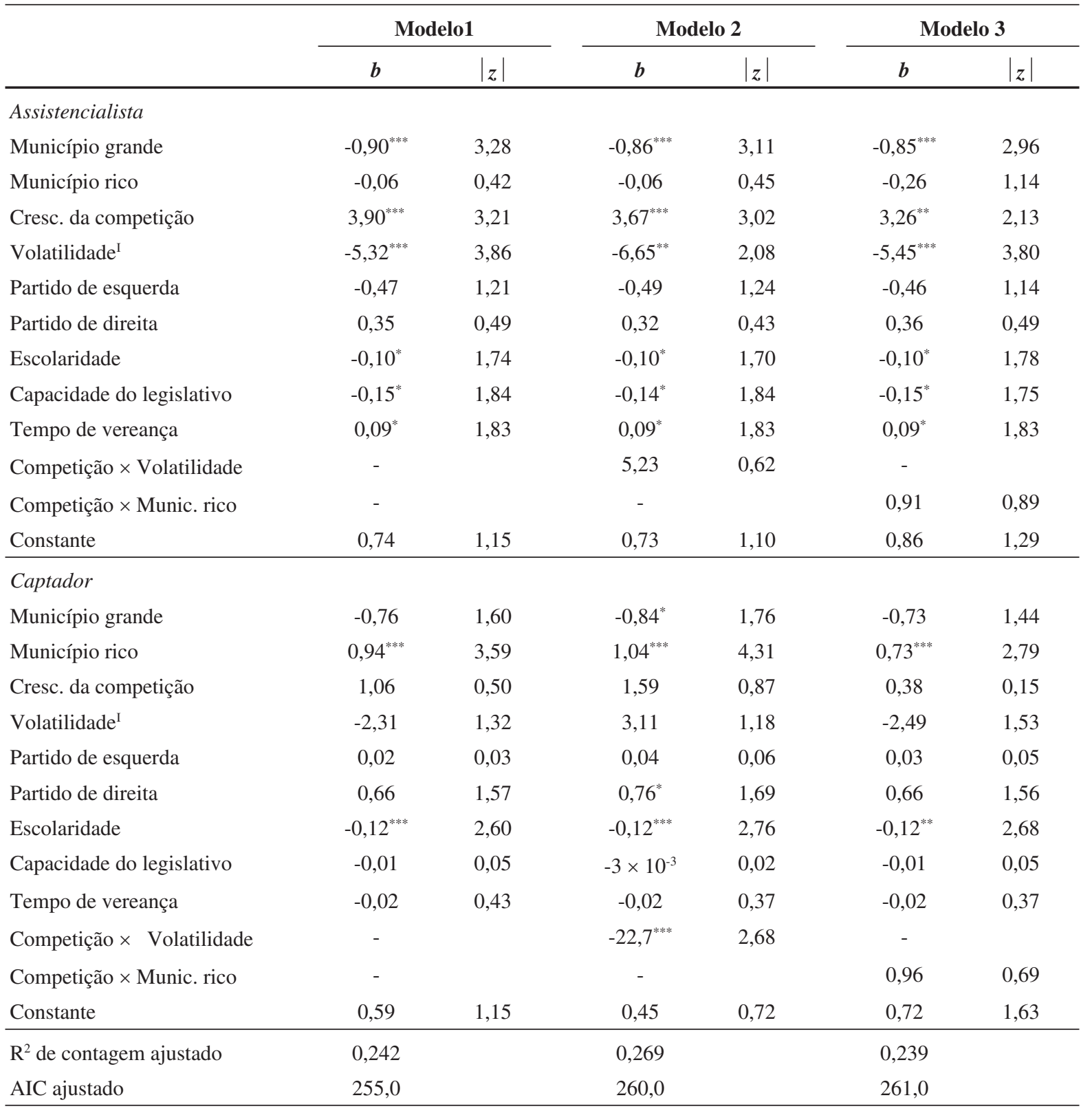

Fonte: Os autores, a partir de TSE (s.d.), SF/SINTER (s.d.) e do banco de dados da pesquisa.

Observações: 1) Categoria base é o tipo "legislador". 2) N=112.3) Estatística z calculada com base em erro padrão sanduíche para clusters de município.

${ }^{\mathrm{I}}$ Centrada na média amostral.

${ }^{*} \mathrm{p}<10 \%,{ }^{* *} \mathrm{p}<5 \% \mathrm{e}^{* * *} \mathrm{p}<1 \%$, em teste bicaudal. 
estimativas do modelo original com as de outro, que restringe a zero os coeficientes relativos a uma das categorias. Note-se, por fim, que a versão probit do modelo multinomial não requer o pressuposto de independência de alternativas irrelevantes.

${ }^{26}$ Agradecemos a um parecerista anônimo por salientar a necessidade dessa qualificação.

27 A respeito dessas medidas, ver respectivamente Long (1997, p.108) e Burnham e Anderson (2004, p.270).
${ }^{28}$ Note-se que a soma das mudanças nas probabilidades dos três tipos é sempre igual a um. $\log$, quanto mais simétricas as mudanças relativas a dois tipos, mais próxima de zero a mudança relativa ao terceiro. resultados relativos a variáveis ambientais, pela possibilidade de absorverem efeitos de características específicas (não observadas) dos municípios ${ }^{26}$.

Os resultados econométricos corroboram as principais hipóteses sobre os condicionantes do clientelismo. A probabilidade de o vereador ser assistencialista (em vez de legislador) é menor em municípios grandes, crescente no aumento da competição política e decrescente na volatilidade eleitoral. Todas essas relações apresentam forte significância estatística. Embora com bem menos confiança, também se observa que aquela probabilidade é decrescente tanto na capacidade do Legislativo municipal quanto na escolaridade do vereador, e que ela é crescente no seu tempo de vereança. Os indicadores de município rico e de vereador filiado a partido de esquerda apresentam estimativas na direção esperada (negativa), porém sem significância estatística. No que diz respeito ao efeito positivo do aumento da competição política, não há evidência de que ele seja moderado pela volatilidade eleitoral nem pela extensão da pobreza.

A respeito da probabilidade de o vereador ser captador (em vez de legislador), pode-se concluir com elevada confiança somente que ela é maior em municípios ricos e decrescente na escolaridade do vereador. Existe evidência frágil de que ela também é menor em municípios grandes e maior entre vereadores de partido de direita. Face à significância da interação entre crescimento da competição e volatilidade, no modelo 2, calculamos e testamos a estimativa do coeficiente total da primeira dessas variáveis, mas ela não se revelou significativa para nenhum valor da segunda (testes não reportados).

Para avaliação dos ajustes das três especificações do modelo aos dados, computamos o $\mathrm{R}^{2}$ de contagem e o critério de informação de Akaike (AIC), o primeiro ajustado para a maior frequência observada entre as categorias da variável dependente, e o segundo, para a quantidade de variáveis independentes de cada especificação ${ }^{27}$. A primeira medida, que expressa a proporção de casos corretamente previstos pelo modelo, apresenta valores moderados, de cerca de 0,25 . A segunda, embora não tenha interpretação substantiva, é mais apropriada para a comparação de especificações alternativas, pois mede a quantidade de informação perdida pelo modelo estimado, relativamente ao "verdadeiro". Por esse critério, portanto, a inclusão dos termos multiplicativos não melhora o ajuste aos dados. Logo, pode-se concluir que o modelo básico tem melhor desempenho relativo.

Para avaliar a relevância substantiva das estimativas probit multinomial do modelo básico, calculamos a mudança discreta na probabilidade estimada de cada categoria da variável dependente associada a um aumento em cada variável independente, mantendo-se as demais fixas. Os aumentos que utilizamos foram de uma unidade, para as variáveis binárias, e de dois desvios padrão, para todas as demais. O Gráfico 2 mostra a magnitude da mudança na probabilidade estimada (eixo horizontal) para cada categoria da variável dependente (pontos do gráfico) como função do aumento de cada variável independente (eixo vertical).

A maior parte das variáveis cujas estimativas se mostraram estatisticamente significativas apresentam impactos substanciais e simétricos nos tipos legislador e assistencialista, com pouco ou nenhum impacto no captador ${ }^{28}$. Em municípios grandes, a probabilidade de tipo legislador é 0,24 maior, enquanto que a de tipo assistencialista é 0,20 menor. Para cada uma dessas probabilidades, o aumento do crescimento da competição política está associado, respectivamente, a uma diminuição de 0,21 e a um aumento de 0,28. Da mesma forma, o aumento da volatilidade eleitoral é acompanhado de aumento de $0,14 \mathrm{e}$ diminuição de 0,17 , respectivamente. Embora menos pronunciada, a simetria também ocorre quando se aumenta a escolaridade: cresce em 0,20 a probabi- 
Gráfico 2 - Mudança nas probabilidades estimadas

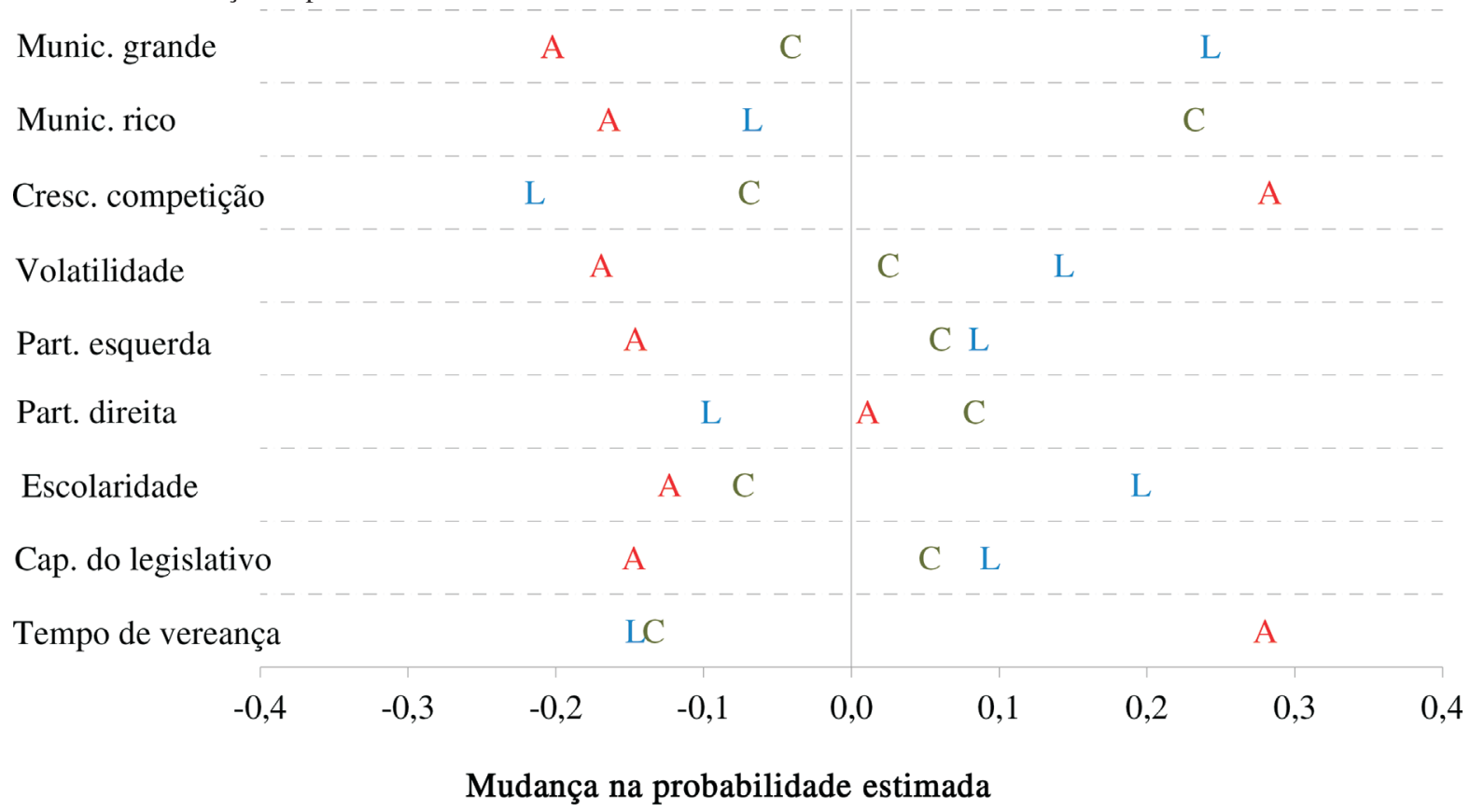

Fonte: Os autores, com base nas estimativas do modelo 1 da Tabela 5.

Legenda: $\mathrm{A}=$ assistencialista, $\mathrm{C}=$ captador e $\mathrm{L}=$ legislador;

Observações: Pontos do gráfico refletem mudança resultante de um aumento (d) na respectiva variável independente, mantendo-se fixos os valores das demais. Definiu-se $d=1$ para variáveis binárias e $\mathrm{d}=2$ desvios padrão para as demais. Os indicadores do tipo do município foram fixados em zero e as demais variáveis, nas suas respectivas medianas amostrais.

lidade de tipo legislador e diminui em 0,12 a de assistencialista. A simetria observada entre os tipos assistencialista e legislador é consistente com nossa premissa de que eles expressam padrões distintos de representação no eixo particularismo-universalismo, e que o primeiro daqueles tipos está mais próximo do primeiro desses polos, enquanto que o segundo tipo, do segundo polo.

Curiosamente, no entanto, o impacto da extensão da pobreza é simétrico não entre os tipos legislador e assistencialista, mas entre cada um deles e o captador. Nos municípios ricos (vis-à-vis os pobres), a probabilidade de tipo captador é maior em 0,23 unidade, enquanto que a de assistencialista e a de legislador menores em 0,16 e 0,07, respectivamente. Essa relação não permite que se trate o tipo captador como categoria intermediária na dimensão universalismoparticularismo. Esse achado demanda maiores investigações, principalmente acerca dos eventuais mecanismos causais que conectam a (menor) extensão da pobreza com a (maior) incidência do padrão de representação do tipo captador.

\section{V.3. Robustez}

Em sete dos 112 casos da amostra tivemos dúvida sobre como classificar o vereador, sempre entre duas alternativas (na maior parte, o assistencialista e o captador). Por isso, refizemos todo o procedimento de estimação com duas outras versões da mesma variável dependente. Na primeira, atribuímos aos sete casos a classificação alternativa e, na segunda, tratamos esses casos como missing, excluindo-os da análise. Em ambas versões, a distribuição dos tipos permaneceu praticamente inalterada, assim como as conclusões a respeito tanto da adequação como do ajuste dos modelos de regressão. As estimativas do modelo básico, por sua vez, apresentaram diferenças que alteraram algumas conclusões secundárias, sem comprometer os principais achados. 
${ }^{29}$ A conversão teve por objetivo eliminar a variação trivial entre municípios de tamanhos muito diferentes. A transformação logarítmica foi motivada por a variável convertida ter distribuição muito inclinada à direita (coeficiente de assimetria igual a 2,12).

${ }^{30}$ Para fins de identificação, a equação de seleção precisa incluir pelo menos uma variável relevante que não faz parte da equação de resultado. Nosso critério de exclusão foi apresentar p-valor superior a 0,60 . A evidência corrobora $o$ pressuposto de que as equações não são independentes entre si $(\rho \neq 0)$.
Nossa principal preocupação, contudo, é com o risco de a variável dependente conter viés de subjetividade dos codificadores. Por isso, também refizemos a análise de regressão utilizando outra variável dependente, livre desse risco. A nova variável, de natureza quantitativa, é a média mensal de pedidos particulares recebidos pelo vereador, tal como declarado por eles. Trata-se, a nosso ver, de boa proxy para a intensidade do assistencialismo entre os vereadores, mas que apresenta a importante limitação substantiva de não capturar a distinção qualitativa do captador.

Para fins de estimação, os valores dessa variável foram convertidos em unidades de mil eleitores do município e, em seguida, transformados em $\log$ aritmo $^{29}$. E para levar em conta que parcela substancial $(30,9 \%)$ dos vereadores não atende pedidos particulares, estimamos um modelo de seleção Heckit, com equação de seleção definida para a decisão do vereador de atender (ou não) pedidos particulares. O Apêndice 2 apresenta as estimativas desse modelo, que omite variáveis cujas estimativas mostraram-se muito distantes do nível convencional de significância ${ }^{30}$.

No geral, os resultados são bastante consistentes com os originais. Embora com algumas diferenças estatísticas, observa-se que, como no probit multinomial, o assistencialismo é menor nos municípios grandes, crescente no aumento da competição e na antiguidade do vereador, e decrescente na volatilidade eleitoral. No Heckit, a estimativa negativa de município rico alcança significância, mas apenas na equação de resultado. Entretanto, são substancialmente diferentes dos originais (e, deve-se reconhecer, inesperadas) as estimativas positivas e significativas de escolaridade e capacidade do legislativo, respectivamente na equação de resultado e na de seleção.

Pelo menos para a escolaridade é possível oferecer uma interpretação (tentativa) que seja teoricamente consistente. $\mathrm{O}$ fato de essa variável apresentar estimativa negativa na equação de seleção e positiva na de resultado significa que a probabilidade de o vereador atender pedidos particulares diminui com a sua escolaridade, e que, dada sua decisão de atender esses pedidos, a intensidade com que ele os recebe aumenta com a sua escolaridade. Nossa interpretação para esse resultado é que a escolaridade funciona como uma proxy para a capacidade do vereador de atender pedidos particulares, principalmente no sentido de construir e manter redes de relacionamento com pessoas que detém recursos importantes para esse atendimento.

Enfim, à luz dessas análises suplementares, parece-nos correto concluir que os resultados da análise de regressão dos tipos de vereadores não apresentam viés de subjetividade relevante.

Neste artigo, procuramos contribuir para a identificação e a compreensão de diferentes tipos de padrões de representação política local, com ênfase no fenômeno do clientelismo, tendo como objetivo mais distante avançar na compreensão da política nos municípios brasileiros. Acreditamos que esse esforço de investigação se justifica pelo descompasso entre a relevância do fenômeno e a (parca) produção de pesquisa empírica.

Entrevistas com 112 vereadores de 12 municípios mineiros revelaram que a representação local é exercida seguindo-se tanto princípios clientelistas quanto universalistas, sendo a incidência do clientelismo menor do que a literatura e o senso comum usualmente apontam ou pressupõem. Embora a maioria relativa $(40,2 \%)$ dos vereadores dedique-se ao assistencialismo, número não muito menor $(35,7 \%)$ deles dedica-se às funções formais do cargo. Constatamos ainda um terceiro padrão de representação, centrado na captação de recursos públicos 
para o atendimento de pedidos coletivos, que ocorre com frequência ainda menor $(24,1 \%)$. A evidência sugere que essas estratégias de representação são qualitativamente diferentes e que elas podem ser entendidas como alternativas de escolha do vereador.

Os resultados da análise dos potenciais correlatos desses padrões de representação sugerem que a probabilidade de um vereador adotar a estratégia assistencialista é significativamente maior em municípios pequenos, crescente no acirramento da competição política e decrescente na volatilidade eleitoral. Encontramos também evidência fraca de que essa probabilidade é menor entre vereadores mais recentes e entre os com maior nível educacional. Ou seja, a incidência do clientelismo na política local brasileira depende de fatores demográficos, políticos e (na medida em que educação está associada a valores políticos) culturais, de maneira bastante coerente com o esperado com base na literatura sobre o fenômeno.

Contrariamente ao esperado, no entanto, não encontramos efeito sistemático da extensão da pobreza sobre a incidência do clientelismo, exceto que em municípios ricos a quantidade de pedidos particulares recebidos pelos vereadores é menor. Curiosamente, o principal efeito da extensão da pobreza parece ser o de diminuir a incidência da estratégia de representação que enfatiza o atendimento de pedidos coletivos, em detrimento das demais. Podemos apenas esperar que esse achado, assim como a frustrante constatação de que a teoria não é adequada para explicar essa estratégia, instigue futuras investigações.

Tal como alertamos ao fim da terceira seção, esses resultados baseiam-se em uma amostra de conveniência de vereadores mineiros eleitos em 2008, em municípios urbanos de regiões não metropolitanas, e que autoriza apenas inferências correlacionais. Embora, do ponto de vista substantivo, não vejamos motivo para suspeitar que os parâmetros de correlação difiram entre essa subpopulação e a população de vereadores brasileiros eleitos naquele ano, do ponto de vista estatístico as inferências devem ser restritas, na melhor das hipóteses, àquela subpopulação.

Por fim, uma nota sobre o papel dos vereadores na política local. Procuramos demonstrar que a representação política é exercida com base em lógicas e estratégias distintas. Tais estratégias provavelmente produzem resultados coletivos diferentes, uns mais e outros menos eficientes. Contudo, independentemente de adesões normativas a modelos de representação, deve-se considerar que, em qualquer dos casos, o vereador é um potencial mediador entre as demandas dos cidadãos e o poder público. Por ter mais oportunidades de conhecer de perto as necessidades dos cidadãos, o vereador pode melhor identificar, por exemplo, quais serviços públicos são deficientes. Não se deve subestimar a relevância desse papel para aprimorar a qualidade das políticas públicas e, por extensão, da democracia.

Felix Lopez (felix.lopez@ipea.gov.br) é Doutor em Sociologia pela Universidade Federal do Rio de Janeiro (UFRJ) e Pesquisador do Instituto de Pesquisa Econômica Aplicada (IPEA). Vínculo Institucional: Instituto de Pesquisa Econômica Aplicada, IPEA, Rio de Janeiro, RJ, Brasil.

Acir Almeida (acir.almeida@ipea.gov.br) é Doutorando em Ciência Política pelo Instituto Estadual de Estudos Sociais e Políticos da Universidade do Estado do Rio de Janeiro (IESP/UERJ) e Pesquisador do IPEA. Vínculo Institucional: Instituto de Pesquisa Econômica Aplicada, IPEA, Rio de Janeiro, RJ, Brasil.

\section{Referências}

Afonso, J., 2010. Federalismo, sistema tributário e fiscal: avaliação do caso brasileiro. Apresentação no IPEA. Brasília, 22 set. Almond, G.A. \& Verba, S., 1989. The Civic Culture: Political Attitudes and Democracy in Five Nations. Newbury Park: Sage Publications. 
Bailey, F.G., 2001. Stratagems and Spoils: A Social Anthropology of Politics. Boulder: West View Press.

Brancaleone, C., 2008. Comunidade, sociedade e sociabilidade: revisitando Ferdinand Tönnies. Revista de Ciências Sociais, 39(1), pp.98-104.

Briquet, J., 1998. La politique clientélaire. Clientélisme et processus politiques. In J. Briquet \& F. Sawicki, eds. Le clientélisme politique dans les sociétés contemporaines. Paris: Presses Universitaires de France.

Burnham, K.P. \& Anderson, D.R., 2004. Multimodel Inference: Understanding AIC and BIC in Model Selection. Sociological Methods and Research, 33(2), pp.261-304. DOI: 10.1177/0049124104268644

Campbell, J.L.; Quincy, C.; Osserman, J. \& Pedersen, O.K., 2013. Coding In-Depth Semistructured Interviews: Problems of Unitization and Intercoder Reliability and Agreement. Sociological Methods and Research, 42(3), pp.294-320. DOI: $10.1177 / 0049124113500475$

Carvalho, J.M., 1997. Mandonismo, coronelismo, clientelismo: uma discussão conceitual. Dados, 40(2), pp.229-250. DOI: 10.1590/s0011-52581997000200003

Castro, M.M.M.; Anastasia, F. \& Nunes, F., 2009. Determinantes do comportamento particularista de legisladores estaduais brasileiros. Dados, 52(4), pp.961-1001. DOI: 10.1590/s0011-52582009000400005

Collier, D.; Brady, H.E. \& Seawright, J., 2010. Sources of Leverage in Causal Inference: Toward an Alternative View of Methodology. In H.E. Brady \& D. Collier, eds. Rethinking Social Inquiry: Diverse Tools, Shared Standards. $2^{\mathrm{a}}$ ed. New York: Rowman and Littlefield Publishers.

Dahl, R.A., 1989. Democracy and Its Critics. New Haven: Yale University Press.

Davis, J., 1977. People of the Mediterranean: An Essay in Comparative Social Anthropology. London: Routledge.

Fried, B.J., 2012. Distributive Politics and Conditional Cash Transfers: The Case of Brazil's Bolsa Família. World Development, 40(5), pp.1042-1053. DOI: 10.1016/j.worlddev.2011.09.022

García-Guadilla, M.P. \& Pérez, C., 2002. Democracy, Decentralization, and Clientelism: New Relationships and Old Practices. Latin American Perspectives, 29(5), pp.90-109. DOI: 10.1177/0094582x02029005006

Graham, R., 1997. Clientelismo e política no Brasil do século XIX. Rio de Janeiro: Editora UFRJ.

Hicken, A., 2011. Clientelism. Annual Review of Political Science, 14, pp.289-310. DOI: 10.1146/annurev.polisci.031908.220508

Hilgers, T., 2011. Clientelism and Conceptual Stretching: Differentiating among Concepts and among Analytical Levels. Theory and Society, 40(5), pp.567-588. DOI: 10.1007/s11186-011-9152-6

Joffre Neto, J.M., 2003. Câmaras municipais no Brasil: ascensão e declínio. São Paulo: EAESP-FGV.

Kerbauy, M.T.M., 2005. As câmaras municipais brasileiras: perfil de carreira e percepção sobre o processo decisório local. Opinião Pública, 11(2), pp.337-365. DOI: 10.1590/s0104-62762005000200003

Kitschelt, H., 2000. Linkages between Citizens and Politicians in Democratic Polities. Comparative Political Studies, 33(6-7), pp.845-879. DOI: 10.1177/001041400003300607

Kitschelt, H. \& Wilkinson, S.I., 2007. Citizen-Politician Linkages: An Introduction. In H. Kitschelt \& S.I. Wilkinson, eds. Patrons, Clients, and Policies: Patterns of Democratic Accountability and Political Competition. New York: Cambridge University Press.

Kushnir, K., 2000. O cotidiano da política. Rio de Janeiro: Jorge Zahar Editor.

Leal, N., 1997. Coronelismo, enxada e voto: o município e o regime representativo no Brasil. Rio de Janeiro: Editora Nova Fronteira.

Lizzeri, A. \& Persico, N., 2005. A Drawback of Electoral Competition. Journal of the European Economic Association, 3(6), pp.1318-1348. DOI: 10.1162/154247605775012888

Long, J.S., 1997. Regression Models for Categorical and Limited Dependent Variables. Thousand Oaks: SAGE Publications.

Lopez, F., 2004. A política cotidiana dos vereadores e as relações entre Executivo e Legislativo em âmbito municipal. Revista de Sociologia Política, 22, pp.153-177. DOI: 10.1590/s0104-44782004000100012

Medina, L.F. \& Stokes, S.C., 2007. Monopoly and Monitoring: An Approach to Political Clientelism. In H. Kitschelt \& S.I. Wilkinson, eds. Patrons, Clients, and Policies: Patterns of Democratic Accountability and Political Competition. New York: Cambridge University Press.

Montero, A.P., 2012. A Reversal of Political Fortune: The Transitional Dynamics of Conservative Rule in the Brazilian Northeast. Latin American Politics and Society, 54(1), pp.1-36. DOI: 10.1111/j.1548-2456.2012.00141.x

Nunes, E., 1997. A gramática política do Brasil: clientelismo e insulamento burocrático. Rio de Janeiro: Jorge Zahar Editor.

Palmeira, M. \& Goldman, M. eds., 1996. Antropologia, voto e representação política. Rio de Janeiro: Contracapa.

Palmeira, M. \& Heredia, B., 2010. Política ambígua. Rio de Janeiro: Relume-Dumará.

Piattoni, S., 2001. Clientelism, Interests, and Democratic Representation. In S. Piattoni, ed. Clientelism, Interests, and Democratic Representation. New York: Cambridge University Press.

Power, T.J. \& Zucco Jr., C., 2009. Estimating Ideology of Brazilian Legislative Parties, 1990-2005. Latin American Research Review, 44(1), pp.218-246. DOI: 10.1353/lar.0.0072

Queiroz, M.I.P., 1976. O mandonismo local na vida política brasileira. São Paulo: Alfa-Ômega.

Rae, D.W., 1995. Using District Magnitude to Regulate Political Party Competition. The Journal of Economic Perspectives, 9(1), pp.65-75. DOI: 10.1257/jep.9.1.65

Schmidt, S.W.; Guasti, L.; Landé C.H. \& Scott, J.C., eds., 1977. Friends, Followers, and Factions: A Reader in Political Clientelism. Berkeley: University of California Press. 
Smith, T.M.F., 1983. On the Validity of Inferences from Non-Random Sample. Journal of the Royal Statistical Society, 146(4), pp. 394-403. DOI: 10.2307/2981454

Stokes, S., 2005. Perverse Accountability: A Formal Model of Machine Politics with Evidence from Argentina. American Political Science Review, 99(3), pp.315-325. DOI: 10.1017/s0003055405051683

Tönnies, F., 1947. Comunidad y sociedade. Buenos Aires: Losada.

Trost, J.E., 1986. Statistically Nonrepresentative Stratified Sampling: A Sampling Technique for Qualitative Studies. Qualitative Sociology, 9(1), pp.54-57. DOI: 10.1007/bf00988249

Vianna, O., 1987. Instituições políticas brasileiras. V. 1. Niterói: EDUFF.

Weingrod, A., 1977. Patrons, Patronage, and Political Parties. In S.W. Schmidt; L. Guasti; C. Landé \& J.C. Scott, eds. Friends, Followers, and Factions: A Reader in Political Clientelism. Berkeley: University of California Press.

Weitz-Shapiro, R., 2012. What Wins Votes: Why some Politicians Opt Out of Clientelism. American Journal of Political Science, 56(3), pp.568-583. DOI: 10.1111/j.1540-5907.2011.00578.x

\section{Outras fontes}

Brasil, s.d. Banco de dados do censo do legislativo 2005. Brasília: Senado Federal/Secretaria Especial do Interlegis.

IBGE. Instituto Brasileiro de Geografia e Estatística, 2000. Indicadores sociais municipais. Disponível em: www.ibge.gov.br/home/estatistica/populacao/indicadores_sociais_municipais/tabelala.shtm. Acesso em: 25 maio 2017.

IPEA. Instituto de Pesquisa Econômica Aplicada, 2010. Brasil em desenvolvimento: Estado, planejamento e políticas públicas. V. 1. Brasília: Ipea. . Ipeadata. Disponível em: www.ipeadata.gov.br. Acesso em: 25 maio 2017.

STN. Secretaria do Tesouro Nacional. Estados e municípios. Transferências voluntárias. Disponível em: www.stn.fazenda.gov.br/estados_municipios/transferencias_voluntarias.asp. Acesso em: 8 maio 2017.

NUAP. Núcleo de Antropologia da Política, 1998. Uma antropologia da política: rituais, representações e violência. Rio de Janeiro: Nau.

TSE. Tribunal Superior Eleitoral. Eleições 2008. Disponível em: www.tse.jus.br/eleicoes/eleicoes-anteriores/eleicoes-2008/eleicoes-2008. Acesso em: 25 maio 2017. 
Legislators, Fundseekers, and Paternalists: Political Representation at the Local Level

\begin{abstract}
The article analyzes political representation at the local level, focusing on the perceptions and everyday practices of councilmembers, particularly their choices between clientelistic and universalist representation strategies. It makes use of original data from semi-structured open interviews with a non-representative sample of 112 councilmembers from twelve municipalities of Minas Gerais, Brazil. By means of qualitative analysis, respondents were classified according to three types, according to their main representation strategy: "legislator", who is more dedicated to the office's formal functions; "fundseeker", who prioritizes the servicing of voters' requests of a collective nature; and the paternalist, who prioritizes servicing requests of a private nature. Based on the theoretical literature on clientelism, it offers explanatory hypotheses about councilmembers' representation strategies, which are tested statistically using a multinomial probit model. The results suggest that these strategies are qualitatively distinct and that the probability of observing the paternalist type is higher in small municipalities, increasing on the sharpening of political competition and decreasing on electoral volatility. There is also weak evidence that this probability decreases with the councilmember's years of schooling and her time in office.
\end{abstract}

KEYWORDS: political representation; clientelism; particularism; councilmember; local politics.

This is an Open Access article distributed under the terms of the Creative Commons Attribution Non-Commercial License which permits unrestricted non-commercial use, distribution, and reproduction in any medium provided the original work is properly cited. 


\section{Apêndices}

Apêndice 1 - Distribuições de características dos vereadores da amostra

\begin{tabular}{|c|c|c|}
\hline Variável & $\mathbf{N}$ & $\%$ \\
\hline \multicolumn{3}{|l|}{ Painel A: Sexo } \\
\hline Feminino & 10 & 8,9 \\
\hline Masculino & 102 & 91,1 \\
\hline Total & 112 & 100 \\
\hline \multicolumn{3}{|l|}{ Painel B: Faixa etária } \\
\hline 18 a 24 & 02 & 1,8 \\
\hline 25 a 34 & 08 & 7,1 \\
\hline 35 a 44 & 41 & 36,6 \\
\hline 45 a 59 & 50 & 44,7 \\
\hline 60 ou mais & 11 & 9,8 \\
\hline Total & 112 & 100 \\
\hline \multicolumn{3}{|l|}{ Painel C: Escolaridade } \\
\hline Fundamental incompleto & 26 & 23,2 \\
\hline Fundamental completo & 23 & 20,5 \\
\hline Médio completo & 34 & 30,4 \\
\hline Superior completo & 29 & 25,9 \\
\hline Total & 112 & 100 \\
\hline \multicolumn{3}{|l|}{ Painel D: Ocupação (além da vereança) } \\
\hline Trabalhadores manuais não especializados & 04 & 3,6 \\
\hline Trabalhador especializado de apoio; autônomo & 25 & 22,3 \\
\hline $\begin{array}{l}\text { Pequeno empresário, produtor ou comerciante; trabalhador ou servidor } \\
\text { público de nível técnico }\end{array}$ & 44 & 39,3 \\
\hline $\begin{array}{l}\text { Empresário, produtor rural ou comerciante; profissional liberal; } \\
\text { trabalhador ou servidor público com cargo de gerência ou direção }\end{array}$ & 39 & 34,8 \\
\hline Total & 112 & 100 \\
\hline \multicolumn{3}{|l|}{ Painel E: Quantidade de mandatos de vereador } \\
\hline $\mathrm{Um}$ & 58 & 51,8 \\
\hline Dois & 28 & 25,0 \\
\hline Três & 14 & 12,5 \\
\hline Quatro ou mais & 12 & 10,7 \\
\hline Total & 112 & 100 \\
\hline
\end{tabular}

Fonte: Os autores. 
Apêndice 2 - Estimativas Heckit da quantidade mensal de pedidos particulares recebidos

\begin{tabular}{lcc}
\hline & $\boldsymbol{b}$ & $|z|$ \\
\hline Equação de resultado & & 1,64 \\
Município grande & $-0,96$ & 1,84 \\
Município rico & $-0,56^{* *}$ & 1,01 \\
Crescimento da competição & 2,26 & 2,75 \\
Escolaridade & $0,13^{* * *}$ & 1,87 \\
Tempo de vereança & $0,04^{* *}$ & 0,32 \\
Constante & 0,16 & 2,31 \\
\hline Equação de seleção & & 0,97 \\
Município grande & $-2,44^{* *}$ & 1,70 \\
Município rico & $-0,18$ & 2,07 \\
Crescimento da competição & $4,36^{* *}$ & 1,75 \\
Volatilidade & $-2,02^{* *}$ & 2,04 \\
Escolaridade & $-0,09^{*}$ & 4,03 \\
Capacidade do legislativo & $0,30^{* *}$ & 2,60 \\
Tempo de vereança & $0,08^{* * *}$ & $1,96^{* * *}$ \\
Constante & 0,025 & \\
\hline Ho: $\rho=0$ (p-valor) & & \\
\hline
\end{tabular}

Fonte: Os autores, a partir de TSE (s.d.), SF/SINTER (s.d.) e do banco de dados da pesquisa.

Observações: 1) Variável de resultado é o logaritmo da quantidade mensal de pedidos particulares recebidos, por 1.000 eleitores. 2) Variável de seleção é um indicador de que o vereador atende pedidos particulares. 3) $\mathrm{N}=108$. 4) Estatística $\mathrm{z}$ calculada com base em erro padrão sanduíche para clusters de município.

${ }^{*} \mathrm{p}<10 \%,{ }^{* *} \mathrm{p}<5 \% \mathrm{e}^{* * *} \mathrm{p}<1 \%$, em teste bicaudal. 